\title{
Noticing the Dead: The Biographical Sketch in Victorian Periodicals
}

\section{JOCK MACLEOD}

Writing about Harriet Martineau in Macmillan’s Magazine in May 1877, John Morley drew attention to the importance of her "biographic sketches" of significant figures in the field of journalism. Martineau, who had died the previous year, had published numerous sketches of the recently dead for the Daily News between 1852 and 1863, many of which were collected in Biographical Sketches (1869). ${ }^{1}$ For Morley, these were "masterpieces in the style of the

vignette. Their conciseness, their clearness in fact, their definiteness in judgment, and above all the rightly-graduated impression of the writer's own personality in the background, make them perfect in their kind." ${ }^{2}$ In reviewing Martineau's work, Morley was himself writing a biographical sketch, a genre that was widespread in periodical literature by the middle of the nineteenth century. Accounts of recently dead editors and contributors ranged from obituaries and memoirs to reviews of books (especially biographies, memoirs, and autobiographies), but many were simply brief sketches of recent or earlier nineteenth century journalistic figures. There is a good deal of slippage between these various genres (Martineau in fact refers to her "sketches" as "memoirs which relate to the dead"), ${ }^{3}$ even though loose distinctions can be made between them. Obituaries, for example, while constituting a key part of what Laurel Brake has termed the "messy scramble at the point of death" in the daily and weekly press, tended to be shorter than Martineau's "sketches." The latter, though published in the daily press very soon after the death of a notable person, typically ranged from 2,500 to 3,500 words and attempted to "convey the impression which the . . life left in each case upon my own mind, and I believe, on that of the society of its time." ${ }^{5}$ It is precisely Martineau's developed sense of reflection (the "definiteness in judgment," as Morley put it) and her ability to record her "impressions" that seem to distinguish her sketches from typical shorter forms of obituary. 
In this essay, I offer a preliminary account of the genre of the biographical sketch and suggest directions for further research and analysis. Sketches of dead writers can be differentiated from those of the living, and in section one I trace out some of the similarities and differences between these two genres. Throughout the essay I use the term "biographical sketch" to refer only to sketches of the dead. Section two then maps the emergence of the biographical sketch as a significant periodical genre in the 1840s and explores possible reasons for its rise in popularity. In sections three and four, I offer an explanation for its efflorescence around the mid-century by analysing the functions of the genre in relation to the formation of periodical writing as a legitimate field. Although I focus on the biographical sketch in making this argument, I also include reviews of biographies, as they are of a similar length and general structure. I conclude by suggesting some further lines of enquiry, based on differences that emerged towards the end of the century, when the field had been successfully established and a process of revaluation was being undertaken. Throughout this analysis, I focus primarily on monthly magazines. Although biographical sketches did appear in the daily and weekly press, the most extended and considered sketches were published in monthlies, where they constituted a recognisable genre in themselves. I pay particular attention to the New Monthly Magazine (1814-84), Blackwood's Magazine (1817-1980), Fraser's Magazine (1830-82), and Tait's Edinburgh Magazine (1832-61) because they all started well before 1840 and continued for many years after, and thus reveal a clear picture of the sketch's emergence as a genre.

\section{Post-mortem and ante-mortem sketches}

Biographical sketches of the recently dead are to be distinguished from what George Saintsbury called the "brief biography, smart in style and somewhat swaggering in manner, of 'Celebrities of the Day,' 'Men of the Time,' and what not."' Saintsbury was referring specifically to the work of William Maginn, whose "Gallery of Illustrious Literary 
Characters," comprising eighty-one portraits (illustrated biographies), had appeared in Fraser's Magazine between 1830 and 1838. Apart from being exercises in Maginn's "compulsive irony and wit," where his contemporaries were frequently made the butt of his satire, the sketches often functioned as opportunities to castigate other magazines, especially those with Whig and reformist leanings, and to extoll the virtues of Fraser's. ${ }^{7}$ There were other similar early series on living celebrities, including profiles of editors and journalists. The most popular of these was Laetitia Landon's “Living Literary Characters," which appeared in the New Monthly Magazine in the early 1830s. ${ }^{8}$ In the early 1850s, the New Monthly continued its practice of generating series of biographies of living celebrities with Francis Jacox's "Literary Leaflets," though by this point some biographies of the dead were also included. Similar projects were well established in the publishing industry. Hazlitt's The Spirit of the Age (1825) was originally published as a series of essays in the London Magazine and the New Monthly, but other collections were generated specifically as book publications. John Watkins's and Fredric Shobal's A Biographical Dictionary of the Living Authors of Great Britain, which appeared in 1816, and Edmund Lodge's Portraits of Illustrious Personages of Great Britain (1823-34) were just two of many such collections of brief biographical sketches of living celebrities which by mid-century had become virtually an industry in themselves. ${ }^{9}$ Indeed, as Alexander Nicolson was to opine in "Biography Gone Mad" in Blackwood's in 1856, the "practice of biographizing living men," had become a ubiquitous form of "spiritual vivisection, or ante-mortem inquests."10

The two genres are not completely separate, of course. Jacox's mixed "Literary Leaflets" show this in practice, and as Julie Codell has argued in relation to artists' biographies in the periodical press, "serialized biographies ranged from Old Masters to moderns, embedding moderns into a tradition it was also simultaneously creating." 11 Nevertheless there are differences. In particular, biographies of the living typically acted as 
illustrations for larger claims about "the spirit of the age," to use Hazlitt's pervasive term. ${ }^{12}$ In effect, they functioned as "types" that were intended to help readers interpret the current cultural and political landscape, a function not entirely dissimilar from the panoramic sketches of "cityscapes and ... the changing social body inhabiting them" examined by Martina Lauster in Sketches of the Nineteenth Century (2007). As Lauster notes, in urban sketches “'character' is superseded by 'type,' and the Lavaterian business of deciphering virtues or vices from individual features gives way to an anatomy of the living social body."13 In the case of Maginn's "Gallery," for example, as Judith Law Fisher observes, "repeated patterns of presentation as well as type-casting established a characteristic Fraserian celebrity."14 In contrast, sketches of the dead function more like traditional biographies in that they attempt to delineate that which is particular to the subject and especially that which is of lasting value, both in the individual's character and in his or her writings. "It is different with the dead," as George Holyoake put it in 1845, because "their characters are formed, the veil is removed, and the picture can be contemplated." 15 Textual and visual representations of living men of letters in the periodical press were a key component of what Richard Salmon has argued was the "increasing professionalization of personal identity" that helped form the Victorian literary profession. ${ }^{16}$ While sketches of the dead had the potential to do this through veneration of those who had passed, the sense of immediacy framed by sketches of the living at work and the potential engagement they generated with readers had a powerful effect on the shifting intellectual terrain in which conflicting and ambiguous notions of genius and professionalism were being worked through. In this context, it is worth noting the differences between the visual sketches that often accompanied the texts of ante-mortem and post-mortem biographies. Living celebrities were invariably represented in personal poses that "typified" them, such as reading or writing at home; the dead, on the other hand, were almost always memorialized in full facial sketches. Living writers in effect were cultural 
goods that could be utilised in a competitive marketplace. As David Latané has remarked in relation to the treatment of Bulwer in Fraser's, "Maginn and James Fraser knew that a good spat caused sales to perk up." ${ }^{17}$ Such a function was not available in quite the same way to dead writers.

Sketches of living men and women of letters appeared regularly in the periodical press beginning in the 1820 s, but sketches of dead men of letters barely existed in the periodical press before the 1840s. ${ }^{18}$ With the single exception of an "In memoriam" entry on Cobbett that focused primarily on his political activities, Maginn's “Gallery" in Fraser's did not include pieces on dead journalists or editors. ${ }^{19}$ Nor did Landon's, even though Hazlitt had died in 1830, Lamb and Coleridge in 1834, and Cobbett in 1835. Some memorials of dead journalists did appear in the 1820s and 1830s, but they were few and far between. In the twenty-odd years between 1817 and 1840, Blackwood's Magazine, for instance, published only George Groly's “The Life of a Democrat: A Sketch of Horne Tooke” in two parts in 1833, and "The Death of Mr Blackwood" by J. G. Lockhart in 1834. Like Fraser's, the New Monthly Magazine devoted space to living contemporaries rather than to the recently dead. Landon's "Living Literary Characters," as the name suggests, is representative in this respect. As Richard Altick remarked many years ago, "The editors of the literary weeklies and monthly magazines, sensing the new, seemingly inappeasable public interest in living writers as persons, devoted generous space to them." ${ }^{20}$ Landon herself, for example, though she was afforded a sketch in Fraser's Magazine in October 1833 while she was still alive, received no notice after her death in 1838. I could only locate three such notices in the New Monthly before 1840. ${ }^{21}$ Tait's Edinburgh Magazine seems to be something of an exception, publishing several biographical pieces in the 1830 s by Christian Johnstone. ${ }^{22}$ These included entries on Cobbett (1835), Coleridge (1836), and Hazlitt (also 1836), together with reviews of Joseph Cottle's Recollections of Coleridge (1837), Thomas Talfourd's Letters and Life of 
Charles Lamb (1837), and Lockhart's Life of Sir Walter Scott (1838). Despite Johnstone's contribution, the overwhelming picture we are left with is that in the monthly periodical press of the 1830 s, the "ante-mortem" biographical sketch completely dominated its "post-mortem" relative.

Understandably, scholarly attention has been devoted largely to the ante-mortem sketch, with Maginn's "Gallery” of particular interest. Typically the focus has been on the role and the construction of literary celebrity in emerging notions of the professional author during the $1830 \mathrm{~s} .{ }^{23}$ However, the sudden proliferation of post-mortem biographical sketches in the 1840 s makes them an interesting and potentially significant cultural phenomenon as well, especially since they came to be published at least as frequently as sketches of the living and were even more ubiquitous during the next twenty years.

\section{The Emergence of the Biographical Sketch}

Why did post-mortem biographical sketches of editors and journalists emerge so suddenly in monthly magazines during the 1840s, and what caused their efflorescence during the twenty years that followed? In part, there is an obvious and simple answer: these were good decades for journalistic deaths. For example, Thomas Barnes (editor of the Times), Theodore Hook (editor of the Tory John Bull in the 1820s and New Monthly Magazine in the late 1830s) and James Fraser (founder of Fraser's Magazine) all died in 1841. Maginn died in 1842, John Foster of the Eclectic Review in 1843, and Thomas Campbell (editor of the New Monthly Magazine in the 1820s) in 1844. Meanwhile, Leman Blanchard (Monthly Magazine, True Sun, and Examiner), Thomas Hood (editor of the New Monthly Magazine during the early 1840s), Sydney Smith (co-founder and early co-editor of the Edinburgh Review), and Richard Barham (contributor to the New Monthly Magazine) all died in 1845. The 1850s, too, provided further opportunities for post-mortem sketches. The deaths of Francis Jeffrey in 1850, John Gibson Lockhart and John Wilson in 1854, and Robert Rintoul in 1858 were 
among many that were "noticed" in biographical sketches. In short, a generation of journalists and editors who had been born in the last two decades of the eighteenth century and had been key players in the development of the periodical press from the Regency to the early Victorian years all died within a decade or so of each other.

Many of these mid-century biographical sketches suggest a radical disjunction between the time of the earlier generation and the current age. J. C. Robertson's 1855 review in Fraser's of John Wilson's Noctes Ambrosiance, the first volume of his Works, perhaps offers the most striking example of this sense of generational change:

Do you know, reader, what the Noctes Ambrosiance are? Very possibly not; or, if you know it, perhaps you have never read any of them. For they came to an end twenty years ago, when you were most likely unborn, or in the nursery; and since you learnt your letters you have found the reviews, the magazines, the newspapers, the novels in monthly numbers, of your own day enough to satisfy your desire of periodical literature. .. . You don't remember the world before railroads; nor the Reform Bill, nor Catholic Emancipation, nor the Wellington, Goderich, Canning, and Liverpool ministries. ${ }^{24}$

It was this "world before railroads," the "prehistoric age of MAGA," as another writer put it, ${ }^{25}$ that was memorialised in the pages of the mid-century monthlies. Thus, the New Monthly Magazine noticed the deaths of Theodore Hook (1841), Leman Blanchard (1845), Richard Barham (1845 and 1847), Charles Hooton, the Rev J. T. Hewlett and Leman Rede (1847) and Horace Smith (1849), all contributors to the magazine, as well as Thomas Talfourd (1854), John Lockhart Lockhart (1854), and John Wilson (1854). ${ }^{26}$ Cyrus Redding also noticed the death of Thomas Campbell in 1845 in a multi-issue series for the New Monthly (1846-48) that became the basis of his biography. In addition, between 1847 and 1848 Horace Smith published a thirteen-part series in the New Monthly titled "A Greybeard's 
Gossip about His Literary Acquaintances" which included recollections of Thomas Barnes, Theodore Hook, John Scott of the London Magazine and John Taylor (editor of the Morning Post). Harrison Ainsworth, by then the proprietor of the magazine, reminisced on many editors in the "Prologue to the Hundredth Volume" in 1854.

Fraser's Magazine tells a similar tale, with pieces on the deaths of Theodore Hook (1841), James Fraser (1841), William Maginn (1842), Thomas Campbell (1844), John Foster (1844), Leman Blanchard (1846), Thomas Moore (1853), John Kemble (1857), David Charles Badham (1857), Robert Rintoul (1858), Richard Ford (1858), William John Broderip (1859), and John W. Parker Jr. (1860). This list is instructive given that Fraser established the magazine, Parker edited it, and Maginn, Badham, Ford, and Broderip were all contributors. Parker, in fact, wrote the pieces on Badham, Rintoul and Broderip before his own death in 1860. Fraser's had become so enamoured of such biographical sketches that by 1862, A. V. Kirwan, a regular contributor to the magazine in the 1850 s, published a three-part series of articles entitled "Editors and Newspaper Writers of the Last Generation." His focus was the daily rather than the monthly press (though many of his subjects wrote for both), but the conception that there was a "last generation" of editors and reporters to be memorialised clearly resonated at the time.

The contribution of Tait's Edinburgh Magazine to post-mortem biography actually declined in the 1840s and 1850s until the periodical's demise in 1861. During the final two decades of its existence, it published fewer sketches and more reviews of biographies of journalists or writers/intellectuals who had contributed to periodical journalism. There is no clear explanation as to why it should go against the trend, but it was probably because Christian Johnstone retired in 1846 as did William Tait, and the journal was sold. Indeed, there seem to be more ante-mortem than post-mortem sketches: sketches of the very much alive Edward Bulwer Lytton and Leigh Hunt appeared in 1846, and one of Thomas Macauley 
in 1847 (all by George Gilfillan). ${ }^{27}$ Nevertheless, it published post-mortem sketches after the deaths of Francis Horner (1843), James Calder (1847), Jeffrey (1850), Wilson (1854) and James Montgomery (1855). This list resonates with Tait's Magazine's relatively liberal politics: Horner helped establish the Edinburgh Review, Jeffrey was its longstanding editor, and Macauley was a major contributor; Hunt edited the Examiner and other reformist periodicals; Calder co-owned and edited the Englishman; and Montgomery co-owned the Sheffield Iris and contributed to the Eclectic Review. Gifillan himself was a committed advocate of the poor and a reformist theologian, so it is not surprising to find him writing sketches of Hunt and Macauley.

Blackwood's Edinburgh Magazine was slower off the mark. No biographical sketches appeared in the 1840s, though it reviewed Beattie's Life of Campbell in 1849. In the 1850s, it dedicated an article to Francis Jeffrey in 1852, three sketches to John Wilson (perhaps Blackwood's most famous early contributor) in 1854 and 1855, articles on the Rev John Eagles (a long-time Blackwood's contributor) in 1855, and a piece on Sydney Smith (by Margaret Oliphant) in 1856. By the 1860s, though, the magazine had caught the wave, with Oliphant contributing a further article on Wilson in 1862, and a raft of biographical sketches and reviews subsequently appearing throughout the decade.

The multiplication of journalistic deaths in the 1840s and 1850s was a necessary condition for the increased publication of biographical sketches in periodicals, but it does not explain why post-mortem biographical sketches, instead of ante-mortem profiles, should become a dominant biographical form. A further explanation may be found in the growth of biography as a popular form of writing around this time. The increasing publication of diaries, memoirs, reminiscences, and biographies of men of letters contributed significantly to this rapidly expanding field of writing. ${ }^{28}$ So, too, did Carlyle's emphasis on the heroism of the man of letters. ${ }^{29}$ As Julian North puts it, the surge in biographical writing was caused by 
the appearance of the "Lives of Byron, Shelley, the Lake Poets, Felicia Hemans, and Laetitia Landon, published from the 1820 s to the early 1840 s," after which "biographical discourseand literary Lives especially_ became part of the daily fabric of reading." 30 While the rush of biographies of Romantic men of letters contributed significantly to the popularity of the genre, there was also an upsurge of biographies of "hidden" lives, a phenomenon recently described by Juliette Atkinson. ${ }^{31}$ In this context, journalists and editors could have it both ways: they were potentially heroic men of letters in the Carlylean sense, but even if they were not quite of that ilk, they could fit into the category of hidden or obscure lives deemed worthy of recording.

Given the increasing popularity of biography as "part of the daily fabric of reading," it is not surprising that biographical sketches should start to feature in the periodical press, where editors were continually on the lookout for new genres to attract readers. From its inception in 1845, Hogg's Weekly Instructor, for example, had regular sections with headings called "Biographical Sketches," "Portrait Gallery," and "Eminent Living Authors." The first of these was considered important enough to lead each issue immediately after the introductory editorial, at least in the early years. Significantly it took precedence over "Eminent Living Authors.” Although Hogg's was not a monthly, the editor's introductory commentary is germane here: “To the biographical section of our labours, we look forward with a lively interest — an interest sharpened by the conviction that there is no kind of reading more extensively useful, or better adapted to persons of all grades of intellect." 32 In addition to referencing the didactic view of biography that dominated at the time ("no kind of reading more extensively useful"), these editorial remarks are notable because they draw our attention to what must have been a widely held view: that biography was a genre that appealed to a wide reading public ("persons of all grades of intellect") and was thus a mechanism for increasing sales. 
While the above examples capture something of the popularity and uses of biographical sketches in general, they do not explain why recently dead journalists in particular were the subject of so many sketches in the 1840s and 1850s. A different way of approaching the problem is to ask how these biographical sketches functioned in various periodicals of the time. What were their assumptions? What narratives did they tell? What were editors trying to achieve by publishing them? Dallas Liddle has referred to the importance of analysing the "characteristics and functions" of periodical genres for

understanding the "expert system of codes and assumptions that reporters, contributors, editors, and even many readers shared." ${ }^{33}$ His efforts to piece these systems together, both in Dynamics of Genre (2009) and more recently through the notion of "distant reading," provide a valuable method for approaching the functions of periodical genres. Here, however, I am taking a slightly different approach by arguing that the post-mortem biographical sketch, as a genre, marked a key moment in which the field of biographical writing was being constructed and defined. In this sense, it was part of a broader process that incorporated ante-mortem sketches as well as a growing number of histories of the press, including book-length studies and periodical articles. Whereas press histories tended to focus on broad-scale and long-term changes, often emphasising increased press freedom, impartiality, and cultural differentiation, along with the impact of what became known as "public opinion," biographical sketches focused more on the individual characteristics, both personal and professional, of a stratum of editors and journalists. At the most general level, they worked to valorise the profession of the man of letters that was so closely associated with the field of periodical writing; at a more local level, they often functioned to help position periodicals in the field through their association with the individual subject of the biography. In the following two sections, I will elucidate these general and specific functions of the post-mortem biographical genre. 
At the general level, post-mortem biographical sketches, like sketches of the living, contributed to the construction of periodical journalism as a significant field of writing by valorising the subjects of the sketches and the field they helped to create. The general effects of the two forms cross over, but the generic markers are different. Unlike ante-mortem sketches, which represented their subjects as current workers in the field (in the process giving readers insight into the conflicts and dynamics of the field), post-mortem biographical sketches functioned as static memorials or monuments. This is a different kind of valorisation that is typically accomplished in a number of ways. First, the sketches almost always have a strong emotional tenor evincing a sense of loss, particularly the loss of genius or greatness. The emotional dimension of biographical sketches can be read in part as writers memorialising dead friends. But it is more than this. The Fraser's Magazine sketch of Hook (d.1841), for example, begins, "Another green leaf has dropped from the stem of genius into the lap of earth! Theodore Hook is dead!" and ends, “Tread lightly o'er his ashes, ye men of genius, for he was your kinsman." 34 The New Monthly finishes its profile of Hook by exclaiming, "The genius which had illumined so wide an horizon, set in darkness for ever! Peace be with him!" 35 The same quasi-religious emotionalism permeates many biographical sketches of the time. The religiosity is of a piece with Coleridge's notion of a secular clerisy and what David Riede has called Carlyle's "Church of Literature," 36 but the affect generated is significantly more powerful, and potentially draws in the periodical's readers in a process of emotional attachment.

As the quotations above indicate, post-mortem biographical sketches are permeated by Romantic notions of the author as genius. Recent scholarship has examined the contested nature of the concept of genius at the time, but it has tended to treat it in terms of a response to the rise of periodical literature. Thus, the concept could function positively, by separating writers of "genius" from periodical scribblers, or negatively, in the case of well-paid 
periodical writers seeking social respectability, by its "possible associations with transgression, antisociality and disdain for the reading public." 37 The point here, however, is the way the concept was applied to periodical writing. The 1859 New Monthly review of Cyrus Redding's forthcoming Literary Reminiscences and Memoirs of Thomas Campbell (1860), for example, begins on the front foot: "The biography of a man of genius is always more or less interesting and useful... . But in these days of universal competition there must be something in a man to achieve a success. There may be drawbacks_-foibles and frailties common to a fallen nature — but still there must be something marked and even exemplary before any one can now earn distinction from the common herd. Take Thomas Campbell as an example." 38 The piece then continues by spelling out Campbell's foibles, but also those characteristics which make him an example of a "branch of literature with which biography more especially concerns itself." 39 This is the profession of letters, in particular monthly journalism. ${ }^{40}$ In short, monthly periodical writing, like poetry, can exhibit genius, and thus deserves the attention afforded to other genres in the literary field also served by exemplary biographies.

What the departed celebrities stand for is not so much periodical writing as an activity (as with ante-mortem sketches) but periodical writing as an achievement. Often subtitled "In Memoriam," the sketches not only memorialise dead colleagues' personalities and characters but also frequently offer judgements about their writerly achievements. This is where they make claims for the value of periodical discursive writing as a "literary" field. Take, for instance, the sketches of John Wilson in Blackwood's Magazine, Tait's Magazine, and the New Monthly Magazine following his death in $1854 .{ }^{41}$ The Tait's and New Monthly pieces begin by briefly discussing Wilson's character and major events in his life, while Blackwood's limits itself to "recall[ing] and arrest[ing] for a moment the lineaments of the man as he first appeared to us." 42 In each case, the emphasis is on his sporting, "manly" 
characteristics, a larger than life figure "so exuberant with animal spirits, so alive to dear life," as Francis Jacox put it in his New Monthly sketch. ${ }^{43}$ This emphasis carries over into an analysis of his writing, in which character and literary style are assumed to be analogous. Wilson's mercurial spirit is at one with an oeuvre that includes poetry, fiction, and philosophy, as well as extensive discursive essays and literary criticism in Blackwood's. In the words of the Tait's writer, "His prowess in physical sports throws an air of healthy freshness into his pages, such as bookworms can never have at command; and this, with the literary merit of the critical pieces, will always cause the 'Recreations of Christopher North' to maintain a favourite place in every library." ${ }^{44}$

An emphasis on the "literary merit of the critical pieces" is characteristic of all of these sketches, which function as exercises in careful and considered evaluation, where a respectful tone dominates, rather than the frequently irreverent (and sometimes vitriolic) tone characteristic of ante-mortem sketches. Tait's and the New Monthly assess Wilson's poetry, fiction, and philosophy, but agree that his strength lies in his discursive writing. For Jacox, writing for the New Monthly, Wilson's poetry exhibits a "feeling of tedium" and a "tone of unreality." ${ }^{45} \mathrm{He}$ further notes that the "tales are marked by the same languid beauty as the poems. ... But there is a kind of intoning accent in the narrator's voice, which savours of the unreal, and suggests fatigue." ${ }^{\prime 4}$ In contrast, the Noctes Ambrosiance are praised for their "concrete life and dramatic individuality." 47 The biographical sketch of Wilson in Blackwood's limits itself to his essays and literary criticism, but it agrees with Jacox's assessment: "In other respects, opinion has given the preference to his prose over his poetry, and to his essays over his narrative fictions. The judgment has been so general that it is probably just. In poetry, in prose fictions, he seems overmatched by other men: in the field of the discursive essay, with its "numerous prose," he is felt to be unique and unapproachable." ${ }^{48}$ The salient point is that they give validity and status to the field of 
discursive, periodical writing by comparing Wilson's "place” in each form of writing. In so doing, they construct an argument against the dominant view of periodical writing as a trade focused on "scribbling," as Carlyle put it, "for the sake of filthy lucre in the periodicals of the day." $" 49$

The high valuation of Wilson's discursive prose is based on the fact that it is more concrete, alive, and varied than his poetry and fiction. In his poetry and novels, Jacox suggests, Wilson "seemed to play on one string" (174). When he began writing for Blackwood's however, "prodigious variety now characterised him. Into a single article he would crowd a profusion of changeful styles, discursive thoughts, sudden transitions of fancy,- - wit, humour, imagination, philosophy, logic, rhetoric,- reflections grave as Seneca, badinage light as Plautus." ${ }^{50}$ Wilson's discursive writing, in effect, enables him to exercise his imagination and achieve the variety and liveliness that are the accepted hallmarks of literary value. Indeed, as Jacox has it, there "are criticisms from his pen hardly to be surpassed in our literature-so richly stored are they with original thought, lofty imagination, subtle insight, humorous illustration, generous sympathy, and imposing diction."51 The Noctes Ambrosiance, he goes on to say, are "overflowing with humour so unctuous, and animated by a dramatic life so hearty, and made the vehicle of sentiments and opinions often so deep and fresh, that they make up a prominent chapter in the literary history of our own time." ${ }^{52}$ This close connection between literary criticism and literature is also taken up in the Blackwood's sketch, which argues that Wilson, through his "services to this Magazine," also "served literature," "investing criticism itself with something of the creative and poetic character of the great works of imagination to which it was to be applied." 53

While all the sketches agree that Wilson's periodical writing was worthy of the same evaluative attention as his poetic and fictional writing, they differ in their final judgements on it. Understandably, Blackwood's lavishes praise on one of its most famous contributors: 
Wilson's contribution was "to enlarge the basis of our critical view, to exchange the criticism of particulars for that of generals, to contemplate and decide according to the essence rather than the form." 54 The liberal Tait's is much less generous in its sketch, emphasising Wilson's "political and literary partisanship," which defined "Jeffrey and his contributors . . as targets — everything that was Whiggish in politics was ruthlessly assailed—and everything that was Cockneyish, or that was supposed to be Cockneyish, which was the same, was smashed indiscriminately." 55 In the Tait's sketch, it is Wilson's partiality that causes his lack of permanence. This leads him ultimately to be placed in the same class as an actor: "The actor is applauded to the echo while on the boards, but when he leaves them even the echo dies away. So it is with the critic and writer of the day. He deals with the men and topics of the time, and posterity will not revive old controversies, or hunt after local allusions or personal histories, for the sake of enjoying passages of arms which amused, interested, and perhaps instructed their forefathers." 56 The New Monthly's assessment falls between Blackwood's and Tait's, arguing that Wilson's early criticism demonstrated partisanship but noting that Wilson gradually moved beyond prejudice: "It is hard to read certain criticisms of his on the 'Cockney' school, and Whig or Radical Authorship, without marking the distinct influence of political and social prejudice on his literary taste. That he gradually and signally disenthralled himself from such trammels, may be frankly and admiringly conceded; but from the beginning it was not so." 57

It was the ideological viewpoint of the writer and magazine that determined whether Wilson achieved impartiality, as claimed by Blackwood's and the New Monthly, or instead served as a fundamental exponent of Tory partisanship, as stressed by Tait's. Post-mortem biographical sketches, in this sense, were as much part of the ideologically conflicted periodical field as were sketches of the living. The point, though, is that in all these accounts, Wilson's achievement in discursive writing is taken as seriously as his poetry and creative 
prose and is judged in broadly similar terms. Indeed, as Robertson's 1855 review of Wilson's Works put it, "It is a matter of rejoicing, not of regret, that instead of bending his energies to some great task, he diffused himself in these lawless Blackwoodian outpourings. . . These pieces were his true utterance." ${ }^{58}$ In short, these biographical sketches, like more formal critical studies of dead authors, attempt to sum up the author's contribution to literature. In doing so, they make a case that periodical writing is worthy of such attention and that sincerity, imagination, concrete imagery, and original thought apply as much to journalism as to other literary genres.

As Tait's evaluation of Wilson's career reveals, claims for the status of periodical writing as a form of creative genius can potentially be undermined by the argument that value is based on longevity; periodical writing just might not stand up to the judgement of posterity. Given the pervasiveness of what Andrew Bennett has called the "culture of posterity,"59 other-stronger-claims were also incorporated into biographical sketches. This is where conceiving of literature as a profession, rather than as a body of imaginative works, became especially important. Such an argument was an inherent part of many ante-mortem sketches, with their stress on the professional nature of the writing activity, but it was also taken up in post-mortem biographical sketches. In memorial biographical sketches, though, the emphasis was slightly different. Typically, they not only mapped out the struggles of the writer while he or she was alive but also aimed to assess the posthumous value of their contribution to the profession. This contribution did not have to display genius so much as the achievements of a solid craftsman. Allusions to struggle, and thus hard work, were common in memorials to journalists. In a sketch-like review of Edward Bulwer Lytton's edition of Laman Blanchard's Sketches from Life (1845), Ainsworth writes, "The life of Laman Blanchard, as here written, is a mournful tale; beautifully and touchingly told; and conveying a most impressive lesson. It is the picture of a struggling man of letters - very forcibly and faithfully portrayed — and 
excites a strong sympathy for the class to which the subject of the biography belonged, while it exhibits the dangers and difficulties to which all who embark in so hazardous a profession as that of literature are exposed." 60 The man of letters is a struggling hero but exemplary nonetheless, a man whose achievements are clearly located within the realm of "literature." Significantly, the term "literature" is used to cover a broad spectrum of writing, rather than a circumscribed canon of imaginative literature. Thus Ainsworth goes on to quote approvingly from Bulwer's biography that Blanchard "unquestionably stands high amongst a class of writers in which for the last century we have not been rich - the Essayists whose themes are drawn from social subjects, sporting lightly between literature and manners." 61 As a living writer, Blanchard was associated with struggle "in so hazardous a profession;" as a dead writer he is recognized for his achievements and his high standing among essayists.

In this context, the argument that writing should be seen not as a production of genius but as a craft was also pursued. In Blanchard's case, the difference between the two arguments is highlighted in two separate pieces published shortly after his death. The first, an 1845 biographical sketch in the New Monthly, judges him in relation to what his "genius" might have produced had he not had to struggle financially: "It will be seen that Mr. Blanchard was so occupied by contributing to the periodical press, that he could have no time for the production of any work in which his genius might have had fair scope; and consequently that his writings bear an evanescent character, by no means in accordance with the real quality of his mind." ${ }^{2}$ The second piece, written by Thackeray and published in Fraser's Magazine in 1846, also includes references to Blanchard's "quality of mind" and the limitations of his published work. Written in the form of a letter from "Michael Angelo Titmarsh" in London to the "Reverend Francis Sylvester" in Rome, Thackeray argues for the value of "fleeting literature" provided that it is done "well and honestly, by persons ordained to that calling in life." 63 The author notes that Blanchard's three volumes of essays, though 
"pleasant and often brilliant," "give no idea of the powers of the author, or even of his natural manner." ${ }^{4}$ Yet Blanchard's "education and his habits, his quick, easy manner, his sparkling, hidden fun, constant tenderness and brilliant good humour, were best employed as they were." 65 Thackeray concludes, "Out of a regard for poor dear posterity and men of letters to come, let us be glad that the great immortality number comes up so rarely. Mankind would have no time otherwise, and would be so gorged with old masterpieces, that they could not occupy themselves with new, and future literary men would have no chance of a livelihood. . . . Let us be content with our status as literary craftsmen."66 Thackeray's argument for "our status as literary craftsmen" should be seen in part as a continuation of his criticisms of Bulwer's more heroic concept of the man of letters that had been maintained in the pages of Fraser's since the late 1830s when his Yellowplush Papers appeared. The idea that writing is a spectrum or a range, rather than a series of qualitatively different objects, is made clear a little later in the essay, when Thackeray asserts, "If every man is disappointed because he cannot reach supreme excellence, what a mad, misanthropical world ours would be! . . It requires no vast power of intellect to write most sets of words, and have them printed in a book:- To write this article for instance, or the last novel, pamphlet, book of travels." ${ }^{967}$ While Thackeray's comments here reflect his well-known position on the writer as craftsman rather than genius and his criticism of the culture of posterity, they are not unique to him. Indeed, other memorial sketches share this viewpoint, arguing that periodical writing is a legitimate activity on its own terms. ${ }^{68}$ While "genius" might, in this argument, be a term that is irrelevant to validating Blanchard's writing, his achieved body of work is still key to the judgement ("pleasant and often brilliant"). It is the net achievement at the end of the career that validates the activity, and the biographical sketch is the means to articulate this. As Richard Salmon has argued in relation to Carlyle, we see in the 1830s and 1840s a "palpable sense of unfamiliarity accompanying the emergence of 'Literature' as an autonomous cultural 
field," and it is precisely in this shifting terrain that biographical sketches in the 1840 s and 1850s undertook their validating function. ${ }^{69}$

Post-mortem biographical sketches of the 1840 s and 1850 s thus functioned in a discursive context of multiple and variable debates that had been going on since at least the 1820s about the nature of authorship and the differences between kinds of writing. Many of those debates were predicated on unstable distinctions between the supposed permanence of creative writing and ephemerality of periodical writing, between the assumed originality and sincerity of creative writing and the mere replication of ideas in periodical writing. These debates also addressed the eminence afforded the dead creative writer by posterity and the relative obscurity afforded the living periodical writer. Both ante-mortem and post-mortem sketches were inflected by, and contributed to, debates over such distinctions. In the latter, however, dead journalists were validated as writers worthy of remembrance; even if posterity had not yet arrived, the achievements of their genius and/or craftsmanship could still be assessed in periodicals in ways similar to memorials to dead creative writers. In these biographical sketches, the field of periodical literature was not simply a field of the ephemeral but had something of quality and permanence about it. It had become, in effect, a field with the same kind of status as creative writing, with contributing writers who possessed greater and lesser powers and who were judged by the same criteria as creative writers.

\section{Valoring the Periodical's Position in the Field}

At a more local level, periodicals used post-mortem biographical sketches to position themselves within journalism as a respectable professional field. This was managed in several ways. First, not all dead journalists were granted the honour of a biographical sketch. Those chosen to be noticed in a given periodical were often its past contributors. This was particularly the case with the New Monthly Review, which dedicated all but two biographical sketches published between 1841 and 1854 to those who had contributed to the journal. The 
choice of subject for post-mortem biographical sketches also reflected the cultural and political predispositions of the subject in relation to the journal. As noted earlier, the biographical sketches published in Tait's during the 1840s and 1850s, for example, were dedicated almost exclusively to periodical writers and editors associated with liberal or progressive politics. Francis Jeffrey, for example, was honoured in Tait's after his death in 1850 but did not rate a biographical sketch in the Tory Blackwood's nor in the New Monthly, whose politics had been relatively conservative since the mid-1830s. ${ }^{70}$ Blackwood's did review Lord Cockburn's Life of Lord Jeffrey (1852) but the piece functioned as a vehicle for criticizing Jeffrey, complaining of his "want of earnestness" and asserting that he had "no faith, and no great seriousness."71 Blackwood's and the New Monthly were perhaps simply responding to the political predispositions of their readers. However, they were also using biographical sketches as part of a larger strategy to position themselves as the appropriate vehicles for constructing, circulating and reinforcing those politics, and, as the Blackwood's review suggests, of making claims for their own value as against the "want of earnestness" in others. The presence or absence of particular biographical subjects helped define what the magazine considered to be important and thus how it positioned itself in the field.

The treatment of the same individual by different periodicals not only reveals the ideological antagonisms at work in the periodical marketplace but also reveals less overt ways in which periodicals were trying to position themselves in this emerging field. Take, for example, memorial sketches of Theodore Hook in the New Monthly and Fraser's Magazine. Hook, born in 1788, was well known for his practical jokes and hoaxes. An inveterate theatre-goer, he was a favourite of the Prince of Wales, who secured him the role of accountant general in Mauritius in 1813. Following the discovery of a shortfall of $£ 62,000$, he was recalled in 1817 and was later imprisoned between 1823 and 1825 . Hook had been appointed editor of the Tory John Bull in 1820 partly to support George IV against 
Queen Caroline in the popular press. In the early 1830s, he started publishing in the New Monthly Magazine, becoming editor in 1837, a role he maintained until just before his death in 1841. Not surprisingly, after his death Hook received highly favourable treatment in both Fraser's and the New Monthly, where he was the subject of two pieces, the first a biographical sketch in 1841 after his death and the second in 1849 following the publication of his biography by Barham. Significantly, he received no biographical sketch in Tait's

\section{Edinburgh Magazine.}

The New Monthly sketch, stretching over four and a half pages, is understandably panegyrical about its recent editor. But the panegyric is instructive in the way it plays out. Hook is described as one of the "familiar faces" in the "social circles of the metropolis" during the previous twenty years. ${ }^{72}$ His death thus caused the greatest "blank in convivial society."73 The article emphasises his "brilliant reputation" and his connections to the Prince Regent. "In fact," the writer asserts, "by the brilliancy of his wit, his convivial powers, and his agreeable manners, he quickly enjoyed a position in society that few literary men, by profession, have ever obtained." A4 "welcome guest at the tables of the great,"75 he was dedicated to his New Monthly readers: "The Readers of this Magazine ought to know that the very last employment of his pen was devoted to their entertainment. It was the closing act of a literary career, of which, as becomes us, we will now give a brief sketch." ${ }^{, 76}$ The "performances" of the magazine and its editor are not only accepted and appreciated by high society but by middle-class conservative readers as well. In effect, the middle classes are imagined as sharing Hook and the magazine with the conviviality and jollity of their betters and, by implication, are vicariously drawn into those circles themselves. This use of the postmortem biographical sketch to define the New Monthly as a class periodical—rather than a publication for the masses - reflects the broad content of the magazine. ${ }^{77}$ 
The Fraser's sketch of Hook, at seven double-column pages, is much longer than the biographical notice in the New Monthly, and it functions in a slightly different way. It, like the New Monthly memorial, focuses on Hook's "animal spirits," "genius," and "powers," significantly omitting his two years in gaol from 1823 to 1825 . Here, though, the writer, Anne Mathews, opines, "It was necessary to be acquainted with him personally, and in society, to be able to form anything like a just conception or appreciation of his exceling powers. ... It seemed as if his talent was essentially oral, and refused to give itself wholly to a more permanent means of sustaining his reputation." ${ }^{, 78}$ Unlike the New Monthly sketch, where Hook the social luminary is associated closely with his readers, Fraser's positively separates him from his role in the New Monthly, his talent being "essentially oral." Mathews's sketch consists primarily of examples of Hook's outrageous tricks on friends and others, especially in the world of the theatre, where he was a close friend of the comedian Charles Mathews, presumably the writer's father. For Fraser's readers, then, Hook is constructed as a free-floating genius rather than as the editor of a rival periodical.

Dead journalists, like the living, were co-opted by editors to add prestige to their publications. But whereas the living held out the possibility of further value to come, the dead acted as evidence for the quality of the publication over time and thus the position it could rightfully claim in the field of periodical literature. In effect, the two genres worked in concert, one pointing to the future, the other pointing to the past. That sense of continuous value was a major plank for relatively longstanding periodicals such as Blackwood's and the New Monthly; in particular, it helped counter the esteem attached to the "new," a sobriquet especially valued in the 1810s (when the New Monthly was established) through to the 1820s, 1830s, and 1840s. Such continuity, readers could infer, meant trust. And trusted publications were purchased publications.

\section{Conclusion}


The profusion of post-mortem biographical sketches in the 1840s and 1850s helped construct the field of periodical writing in terms that were being used to validate the broader field of literature, particularly imaginative literature. They acted alongside full-length biographies of men of letters and various ante-mortem sketches that had been appearing in periodical and book collections since the 1820s. Richard Salmon notes that "ephemeral periodicals tended to focus on the living, the dead were considered more suitable for commemoration in books," 79 but in their efforts to valorise the profession of writing, biographical sketches undermined this distinction. While journalists might not yet have joined the ranks of the illustrious dead, they were on the way, and biographical sketches functioned to take them there. These sketches worked not so much to protect or displace the reputation of the subject, as was the case with established men of letters (one thinks of the conflicts surrounding Moore's life of Byron), but to create reputations. More specifically, they also functioned to associate or position periodicals with the illustriousness of those dead writers, thereby attaching something of their value and status to the publication and its readers.

Yet biographical sketches continued throughout the nineteenth century (and of course into the present) long after the field was well established and relatively stable. Further, while they continued to be published throughout the 1860 s and into the 1870 s, there was another significant increase in the second half of the 1870 s that continued into the 1890 s. If my argument about the function of post-mortem biographical sketches at the mid-century holds, why, then, did the genre once again proliferate when the media environment had changed? Answering this question lies beyond the purview of a brief conclusion, but it is worth touching on momentarily because it reinforces the importance of considering the function of the genre as the most effective way to understand it. If we retain the focus on monthlies and consider those that ran from approximately 1860 to the twentieth century, we can discern some suggestive patterns. In addition to Blackwood's Magazine, these monthlies include 
Macmillan's Magazine (1859-1907), Temple Bar (1860--1906), the Cornhill Magazine (1860-1900), Good Words (1860-1911), the Fortnightly Review (1865-1954) and the Contemporary Review (1866-1900), all of which published biographical sketches. Of these, the Cornhill, Fortnightly, and Contemporary each published fewer than a dozen sketches over the forty years, and Good Words limited itself largely to journalists with affiliated religious principles. Consequently, I touch here only on Blackwood's, Macmillan's, and Temple Bar.

In these three monthlies, there were fourteen entries (obituaries or sketches of the recent dead, sketches of earlier journalists and editors, and sketch-like reviews of biographies of journalists) in the 1860s, thirty-six entries in the 1870s (of which twenty-three were in the second half of the decade), thirty-one entries in the 1880s and twenty-eight entries in the 1890s. ${ }^{80}$ Significantly, while Blackwood's maintained its emphasis on the recent dead (seven of nine sketches in the 1870s, six of nine in the 1880s, and three of seven in the 1890s), the rapid increase in biographical sketches in the other periodicals was generated largely by accounts of earlier periodical writers. ${ }^{81}$ This was especially the case in the $1880 \mathrm{~s}$ and $1890 \mathrm{~s}$. Thus, Macmillan's published eight sketches of earlier writers in the 1880s and six in the 1890s, but none of the recently dead; Temple Bar published five in the 1880s and five in the 1890s, with only one post-mortem sketch of a journalist.

If, as this article has suggested, biographical sketches at mid-century were shaped by and in turn helped to shape the cultural debates that constructed periodical literature as a legitimate field, perhaps it could also be argued that in the last quarter of the century, the genre functioned to place earlier writers in what was by then a legitimized field and to give a sense of the longevity of the profession. Unlike the sketches at mid-century, it seems that later sketches largely took the field as a given. They functioned, we might say, at an "advanced" stage of an artistic field, as Bourdieu calls it, "where there is no place for naïfs; 
more precisely, the history is immanent to the functioning of the field, and to meet the objective demands it implies, as a producer but also as a consumer, one has to possess the whole history of the field." ${ }^{82}$ In effect, late century biographical sketches enabled contemporary readers and writers to possess the field as a developing whole; they were, to use Bourdieu's words, "immanent to the functioning of the field."

Such speculations are just one of the possible lines of enquiry into what is an understudied genre. Compared to the significant scholarship on celebrity and sketches of living authors, research on "post-mortem" biographical sketches is almost non-existent. Here I have argued that a productive way of analysing the genre is to consider its function in the development of the field of periodical writing, along with ante-mortem biographical sketches, periodical histories, and the like. This enables us to assess how it relates to those other genres, how its functions change over time, and how it was implicated in and contributed to the cultural dynamics and ideological collisions of the Victorian years. Such an approach enables us to learn more about the genre's "embeddedness in multiple, overlapping contexts," to use David Amigoni's phrase. ${ }^{83}$ The changing stylistic and tonal characteristics of the genre are also worthy of further examination. Existing as it does at the intersection of biography and the periodical sketch, the post-mortem sketch is a significant cultural phenomenon that demonstrates the value of studying broader generic interactions at specific moments in the Victorian period and across different forms of life writing.

Griffith University

\section{NOTES}

${ }^{1}$ The book collection was organised into the following categories: literary, scientific, professional, social, politicians, and royal personages. Martineau's fourteen literary entries 
included three well-known periodical writers such as John Wilson (“Christopher North”), John Gibson Lockhart, and John Wilson Croker, though some of her other subjects, such as Thomas De Quincey and Thomas Macaulay, also wrote for the press. As Martineau notes in her preface to the collection, a few of the sketches related to "persons then living," but the vast majority were written about the recently dead.

${ }^{2}$ Morley, "Harriet Martineau," 59.

${ }^{3}$ Martineau, Biographical Sketches, vi.

${ }^{4}$ Brake, "Death of Heroes," 167.

${ }^{5}$ Martineau, Biographical Sketches, vi.

${ }^{6}$ Saintsbury, "Three Humourists," 112.

${ }^{7}$ Latané, William Maginn, 135. The series was sometimes called the "Gallery of Illustrious Portraits" because each sketch was accompanied by an illustration of the subject by Daniel Maclise. For a valuable analysis of this series, see Fisher, "In the Present Famine." For information on its genesis and Maginn's tone, see Latané, William Maginn.

${ }^{8}$ As Richard Altick has noted, other early series included "Portraits of Authors" in the Champion (1814) and "Sketches of Contemporary Authors" in the Athenceum (1828). Altick attributes the "Living Literary Characters" series in the New Monthly to Allan Cunningham. Altick, Lives and Letters, 128.

${ }^{9}$ The vogue for brief portraits or biographies of living celebrities was also picked up in the book publishing trade. Richard Horne drew on the success of Hazlitt's earlier collection The Spirit of the Age: Contemporary Portraits (1825) in the title of his 1844 A New Spirit of the Age, which focuses on a "new set of men, several of them animated by a new spirit, [who] have obtained eminent positions in the public mind" (1:iv). David Bogue's popular The Men of the Time (1852) was re-published as Men of the Time: Biographical Sketches of Eminent Living Characters; also Biographical Sketches of Celebrated Women of the Time (1856). 
Some collections, like M. F. Conolly's Biographical Dictionary of Eminent Men of Fife (1866) focuses on local notables to attract a potential market.

10 [Nicolson], "Biography Gone Mad,” 286.

${ }^{11}$ Codell, "Constructing the Victorian Artist," 291.

12 The title of Hazlitt's 1825 collection, The Spirit of the Age: Contemporary Portraits, was not only a trigger for Horne's 1844 A New Spirit of the Age (see note 9 above), but for numerous pieces in the periodical press, where use of the phrase was widespread in the late 1820s and early 1830s in particular.

${ }^{13}$ Lauster, Sketches of the Nineteenth Century, 6, 13.

${ }^{14}$ Fisher, "In the Present Famine," 100.

${ }^{15}$ Holyoake, Value of Biography in the Formation of Individual Character (1845), quoted in Atkinson, Victorian Biography Reconsidered, 30.

${ }^{16}$ Salmon, Formation of the Victorian Literary Profession, 5.

${ }^{17}$ Latané, William Maginn, 142.

${ }^{18}$ Recent scholarship identifying the identities of anonymous authors increasingly reveals women's roles in the development of the press. See, for example, Peterson, Becoming $a$ Woman of Letters; Beetham, A Magazine of Her Own?; and Demoor, Their Fair Share. Significantly, though, the vast majority of biographical sketches, at least until the 1880 s, dealt with male journalists and editors, another example of women being written out of the profession of letters. Where I use the term "men of letters," I am referring to the contemporaneous male-centred usage.

${ }^{19}$ As part of the series, Maginn wrote an 1835 obituary for the Tory social reformer and MP Michael Thomas Sadler. Although Sadler had contributed to the Leeds Intelligencer, Maginn focuses on his career in politics. Maginn also published a brief account of the late James Mackintosh in the Law Magazine in 1832. 
${ }^{20}$ Altick, Lives and Letters, 128.

${ }^{21}$ In 1830, the New Monthly published B. W. Proctor's "My Recollections of the Late William Hazlitt"; in 1837 it published a "Memoir of the Rev. G. R. Gleig," who had been a contributor to Blackwood's and the Edinburgh Magazine; and in 1839 it published a "Biographical Notice of the Late John Home," who had written on politics for John Wilkes's North Briton.

${ }^{22}$ Johnstone, with her husband John, a printer, founded the monthly Johnstone's Edinburgh Magazine in 1833, and acted as a sub-editor for the newly established Tait's Edinburgh Magazine. In 1834 Johnstone's was incorporated into Tait's and Mrs. Johnstone was appointed editor.

${ }^{23}$ See, for example, Fisher, "In the Present Famine," and Peterson, Becoming a Woman of Letters.

${ }^{24}$ [J. C. R.], "Noctes Ambrosiance," 363; emphasis in the original. "J. C. R.” is most likely James Craigie Robertson (1813-82), clergyman and biographer. Although Robertson was only forty-two in 1855 , the reminiscences in the piece coincide with aspects of his early years, especially at Cambridge, where he began his studies in 1831.

25 "Review of Christopher North," 762.

${ }^{26}$ Lockhart and Wilson were featured in Francis Jacox's "Literary Leaflets" series which had started in 1852.

${ }^{27}$ Gilfillan's A Gallery of Literary Portraits, published by William Tait in 1845, was based on sketches he had been publishing in the Dumfriesshire and Galloway Herald since 1840. A second series, Modern Literature and Literary Men: Being a Second Gallery of Literary Portraits, appeared in 1849 , and a third series was published in 1854 . The sketches in Tait's mentioned here formed part of the second collection. 
${ }^{28}$ Journalistic biographies included Laman Blanchard's Life and Literary Remains of Laetitia Elizabeth Landon (1841), John Sheppard's Life and Correspondence of John Foster (1847), William Beattie's Life and Letters of Thomas Campbell (1849), Richard Barham's The Life and Remains of Theodore Edward Hook (1849), and Henry Cockburn's Life of Lord Jeffrey (1852). By the 1860s, the genre was even more ubiquitous in print culture.

${ }^{29}$ In the "Advertisement" which prefaces his first Gallery of Literary Portraits, Gilfillan calls himself a "hero-worshipper" who studies the "masterpieces of his country's genius." The men he has selected, he goes on to say, "are, in his judgment, the leading lights - the decora et tutamina - of their age." Gilfillan, Gallery, np.

${ }^{30}$ North, Domestication of Genuis, 3.

${ }^{31}$ Atkinson, Victorian Biography Reconsidered, 16.

${ }^{32}$ Hogg, "Thoughts at Starting," 3.

${ }^{33}$ Liddle, "Genre," 391, 384.

${ }^{34}$ [Mathews], “Theodore Edward Hook,” 518, 524

35 "Memoir of the Late Theodore Hook, Esq.," 141

${ }^{36}$ See Knights, Idea of the Clerisy; Riede, "Transgression."

${ }^{37}$ Higgins, Romantic Genius, 45.

38 “Thomas Campbell," 420.

${ }^{39}$ Ibid., 431.

40 The author in passing derides the "steady, constant, undeviating spirit of detraction" in any “leading critical hebdomadal.” Ibid., 428.

41 "Death of Professor Wilson," "Professor Wilson," and [Jacox], "Professor Wilson." 42 “The Death of Professor Wilson,” 629.

43 [Jacox], "Professor Wilson," 164.

44 "Professor Wilson," 335. 
45 [Jacox], "Professor Wilson,” 168.

${ }^{46}$ Ibid., 173; emphasis in the original text.

${ }^{47}$ Ibid., 168-69.

48 "Death of Professor Wilson," 632.

${ }^{49}$ Thomas Carlyle to Jane Baillie Welsh, 9 January, 1825, in Carlyle, Letters, 3: 246.

${ }^{50}$ [Jacox], "Professor Wilson," 174.

${ }^{51}$ Ibid., 176.

${ }^{52}$ Ibid., 177.

53 "Death of Professor Wilson," 632, 630.

${ }^{54}$ Ibid., 630.

55 “Professor Wilson," 335, 334.

${ }^{56}$ Ibid., 334.

57 [Jacox], "Professor Wilson," 175.

${ }^{58}$ J. C. R., “Noctes Amrosiana,, 376.

${ }^{59}$ See Bennett, Romantic Poets and the Culture of Posterity.

60 Ainsworth, "Laman Blanchard,” 131.

${ }^{61}$ Ibid., 133.

62 "Late Mr. Laman Blanchard," 430.

${ }^{63}$ [Thackeray], “A Brother of the Press,” 333.

${ }^{64}$ Ibid., 335.

${ }^{65}$ Ibid.

${ }^{66}$ Ibid., 334; emphasis in the original.

${ }^{67}$ Ibid., 336-37.

${ }^{68}$ Bulwer had been an object of ridicule in Fraser's since the beginning. Maginn, for example, savagely noted in a Fraser's review in June 1830 that "Mr. Bulwer, it seems, loves 
praise, as boys love their pudding, and his friends have injudiciously stuffed him till he could stuff down no more.” Quoted in Latané, Maginn, 142.

${ }^{69}$ Salmon, Formation of the Victorian Literary Profession, 44.

${ }^{70}$ In the 1820 s, the magazine's politics reflected differences between its Tory owner, Henry Colburn, its Liberal editor, Thomas Campbell, and its reformist sub-editor, Cyrus Redding. See Sweet, "New Monthly Magazine." After a brief period in the early 1830s when it supported the Reform Bill during Bulwer's editorship, it moved towards the Tories under the editorships of Hook and then Thomas Hood before Colburn sold it to William Ainsworth in 1845. During Ainsworth's ownership and editorship, it remained largely conservative, though its politics were less partisan than Blackwood's or Fraser's.

${ }^{71}$ [Smith], "Jeffrey," 273, 274; emphasis in the original.

72 "Memoir of the Late Theodore Hook, Esq.," 137.

${ }^{73}$ Ibid.

${ }^{74}$ Ibid., 139

${ }^{75}$ Ibid., 140.

${ }^{76}$ Ibid., 137.

${ }^{77}$ A full content analysis of the New Monthly lies outside the scope of this essay, and my comment is based on general observations. Taking 1840, the year before Hook's death, as an example, we can see the fiction and poetry contributions are typically by members of the upper middle class (the Hon. Grantley Berkeley, the Hon. Mrs Norton, and the like), with some entries from higher up in the social scale (for example, the Countess of Blessington, who is frequently published, Lady Esther Stanhope and the Marquis of Londonderry). The fiction is usually romance, and often court romance or historical romance. The book reviews, most of which were undertaken by Hook, typically noticed court and historical romances, books about royalty, "tours" of the continent and aspects of empire. The manners and mores 
of the upper levels of society were the meat of both the fictional contributions and the reviews. A much more careful and detailed analysis would be required to unearth authorial perspectives and their positioning of class positions, but on the surface it does seem that contributions largely worked towards integrating their readers with the world of the upper middle classes.

78 [Mathews], "Theodore Edward Hook," 518.

${ }^{79}$ Salmon, Formation of the Victorian Literary Profession, 211.

${ }^{80}$ There is room for some disagreement over these figures. During the forty-year period, there were entries that discussed periodical writers but were not primarily biographical or analytical in intent. That is, they discussed specific journalists and editors but largely in the context of broader historical issues. I have excluded these articles from my study. Of course, where the line is drawn between "primarily biographical" and "largely historical" is a matter of judgement, and it may be that others will draw the line in slightly differently way and thus generate different data. Regardless, the broad pattern of a significant increase from the second half of the 1870 s through to the end of the 1890 s holds true. I would like to acknowledge the immense help provided by Palmegiano's Perceptions of the Press in identifying many of these articles.

${ }^{81}$ Many of these were written by Margaret Oliphant about contributors to the magazine and would have been of relatively little interest to outside readers.

${ }^{82}$ Bourdieu, Field of Cultural Production, 60-61.

${ }^{83}$ Amigoni, "Introduction," 11.

\section{WORKS CITED}

Ainsworth, Harrison. "Laman Blanchard and His Writings, with a Selection from His Correspondence with Mr. Ainsworth.” New Monthly Magazine 76 (February 1846): $131-40$. 
Altick, Richard. Lives and Letters: A History of Literary Biography in England and America. New York: Knopf, 1965.

Amigoni, David. "Introduction." In Life Writing and Victorian Culture, edited by David Amigoni, 1-19. Aldershot: Ashgate, 2006.

Atkinson, Juliette. Victorian Biography Reconsidered: A Study of Nineteenth-Century 'Hidden' Lives. Oxford: Oxford University Press, 2010.

Beetham, Margaret. A Magazine of Her Own?: Domesticity and Desire in the Woman's Magazine, 1800-1914. London: Routledge, 1996.

Bennett, Andrew. Romantic Poets and the Culture of Posterity. Cambridge: Cambridge University Press, 1999.

Bourdieu, Pierre. The Field of Cultural Production. Oxford: Polity Press, 1993.

Brake, Laurel. "The Deaths of Heroes: Biography, Obits and the Discourse of the Press, 1890-1900.” In Life Writing and Victorian Culture, edited by David Amigoni, 16593. Aldershot: Ashgate, 2006.

Carlyle, Thomas, and Jane Welsh Carlyle. The Carlyle Letters Online [CLO]. Ed. Brent E. Kinser. Durham, NC: Duke University Press, 2007-2016. www.carlyleletters.org. Codell, Julie. "Constructing the Victorian Artist: National Identity, the Political Economy of Art and Biographical Mania in the Periodical Press." Victorian Periodicals Review 33, no. 3 (2000): 283-316.

“Death of Professor Wilson.” Blackwood's Edinburgh Magazine 75 (May 1854): 629-32.

Demoor, Marysa. Their Fair Share: Women, Power and Criticism in the Athenaum, from Millicent Garett Fawcett to Katherine Mansfield, 1870-1920. Aldershot: Ashgate, 2000. 
Fisher, Judith L. “'In the Present Famine of Anything Substantial': Fraser's 'Portraits' and the Construction of Literary Celebrity; or, 'Personality, Personality Is the Appetite of the Age." Victorian Periodicals Review 39, no. 2 (2006): 97-135.

Gilfillan, George. A Gallery of Literary Portraits. Edinburgh: William Tait, 1845.

Hazlitt, William. The Spirit of the Age: Contemporary Portraits. London: Henry Colburn, 1825.

Higgins, David. Romantic Genius and the Literary Magazine: Biography, Celebrity and Politics. London: Routledge, 2005.

Hogg, James. “Thoughts at Starting.” Hogg's Weekly Instructor 1 (March 1, 1845): 1-3. Horne, Richard. A New Spirit of the Age. London: Smith, Elder \& Co., 1844.

J. C. R. “Noctes Ambrosiana." Fraser's Magazine 52 (October 1855): 363-78.

[Jacox, Francis]. "Professor Wilson.” New Monthly Magazine 101 (June 1854): 162-79.

[Kirwin, A. V.]. "Editors and Newspaper Writers of the Last Generation.” Fraser's Magazine 65 (February 1862): 169-83, 65 (May 1862): 595-609; 66 (July 1862): 32 49.

Knights, Ben. The Idea of the Clerisy in the Nineteenth Century. Cambridge: Cambridge University Press, 1978.

Latané, David E. William Maginn and the British Press: A Critical Biography. Farnham: Ashgate, 2013.

“The Late Mr. Laman Blanchard.” New Monthly Magazine 73 (March 1845): 428-30.

Lauster, Martina. Sketches of the Nineteenth Century: European Journalism and Its “Physiologies,” 1830-1850. Basingstoke: Palgrave Macmillan, 2007.

Liddle, Dallas. “Genre: 'Distant Reading' and the Goals of Periodicals Research.” Victorian Periodicals Review 48, no. 3 (2015): 383-402. 
[Mathews, Anne]. “Theodore Edward Hook.” Fraser's Magazine 24 (November 1841): $518-24$.

Martineau, Harriet. Biographical Sketches. New York: Leypoldt \& Holt, 1869.

"Memoir of the Late Theodore Edward Hook, Esq." New Monthly Magazine 63 (October 1841): 136-41.

Morley, John. “Harriet Martineau.” Macmillan's Magazine 36 (May 1877): 47-60.

[Nicolson, Alexander]. "Biography Gone Mad.” Blackwood's Edinburgh Magazine 79 (March 1856): 285-304.

North, Julian. The Domestication of Genius: Biography and the Romantic Poet. Oxford: Oxford University Press, 2009.

Palmegiano, E. M. Perceptions of the Press in Nineteenth-Century British Periodicals. London: Anthem Press, 2012.

Peterson, Linda H. Becoming a Woman of Letters: Myths of Authorship and Facts of the Victorian Market. Princeton: Princeton University Press, 2009.

“Professor Wilson.” Tait's Edinburgh Magazine 21 (June 1854): 332-35.

Review of Christopher North: A Memoir of John Wilson, Late Professor of Moral Philosophy in the University of Edinburgh, by Mrs. Gordon." Blackwood's Edinburgh Magazine 92 (December 1862): 751-67.

Riede, David. “Transgression, Authority, and the Church of Literature in Carlyle.” In Victorian Connections, edited by Jerome J. McGann, 88-120. Charlottesville: University Press of Virginia, 1989.

Saintsbury, George. “Three Humourists: Hook, Barham, Maginn.” Macmillan's Magazine 69 (December 1893): 105-15.

[Smith, William Henry]. “Jeffrey.” Blackwood's Edinburgh Magazine 72 (September 1852): 269-84. 
Salmon, Richard. The Formation of the Victorian Literary Profession. Cambridge: Cambridge University Press, 2013.

Sweet, Nanora. "The New Monthly Magazine and the Liberalism of the 1820s." In Romantic Periodicals and Print Culture, edited by Kim Wheatley, 146-62. London: Frank Cass, 2003.

[Thackeray, W. M.]. “A Brother of the Press.” Fraser's Magazine 33 (March 1846): 33242.

“Thomas Campbell.” New Monthly Magazine 117 (December 1859): 420-31. 